\title{
Reforming Land and Water Rights in South Africa
}

DOI:

10.1111/j.1467-7660.2012.01784.x

\section{Document Version}

Accepted author manuscript

Link to publication record in Manchester Research Explorer

\section{Citation for published version (APA):}

Woodhouse, P. (2012). Reforming Land and Water Rights in South Africa. Development and Change, 43(4), 847868. https://doi.org/10.1111/j.1467-7660.2012.01784.x

\section{Published in:}

Development and Change

\section{Citing this paper}

Please note that where the full-text provided on Manchester Research Explorer is the Author Accepted Manuscript or Proof version this may differ from the final Published version. If citing, it is advised that you check and use the publisher's definitive version.

\section{General rights}

Copyright and moral rights for the publications made accessible in the Research Explorer are retained by the authors and/or other copyright owners and it is a condition of accessing publications that users recognise and abide by the legal requirements associated with these rights.

\section{Takedown policy}

If you believe that this document breaches copyright please refer to the University of Manchester's Takedown Procedures [http://man.ac.uk/04Y6Bo] or contact uml.scholarlycommunications@manchester.ac.uk providing relevant details, so we can investigate your claim.

\section{OPEN ACCESS}




\title{
Reforming Land and Water Rights in South Africa ${ }^{1}$ Philip Woodhouse
}

Author accepted manuscript published 2012 in Development and Change 43 (4): 847-868

DOI: 10.1111/j.1467-7660.2012.01784.x

\begin{abstract}
Redress of historical injustice in access to land provided a mobilizing force for the overthrow of the apartheid government in South Africa. Inequality of access to water resources marks South Africa's history even more profoundly than inequality of access to land. Yet in South Africa, post-apartheid legislative reform relating to land and water has followed largely separate, if parallel, paths. This paper traces the development and current status of water reforms in the Inkomati Water Management Area, where water use is dominated by established commercial agriculture and forestry, by important environmental interests, including the Kruger National Park, and by demands for improved access to water from a black population of around 1.5 million living in former Bantustan areas. It indicates that in practice water and land reform are interdependent, but, although both have become more closely linked within local political and economic arenas, they remain largely disconnected and disabled by unresolved tensions within their separate policy processes. The paper argues that the commoditised nature of land and water use within the established patterns of commercial agriculture sets constraints on what redistributive land and water reform can deliver to those historically dispossessed. In particular, increasing recourse to 'strategic partnerships' between African community landowners and commercial agribusiness as a means of maintaining the productivity of commercial farmland poses questions about the control and beneficial use of new forms of communal property.
\end{abstract}

\section{INTRODUCTION}

The establishment of majority rule in South Africa in 1994 was regarded by many South Africans as only a first step in redressing the discrimination and dispossession to which the black population had been subject by previous governments. Key targets of redress were the 1913 Land Act that excluded black South Africans from purchasing land and acquiring freehold titles, and the subsequent (1936) legislation restricting black peoples' settlement to constitutionally-defined 'tribal' reserves. So fundamental was this legislation to the apartheid era that a white paper on its abolition

\footnotetext{
${ }^{1}$ An earlier version of this paper was presented at the International Conference on Land Reforms and Management of Natural Resources in Africa and Latin America, 25-27 November, 2010, in Lleida, Spain. The author wishes to acknowledge the very useful comments of three anonymous referees.
} 
and introduction of a process of land reform was already published in 1991, three years before elections for a new government.

While discrimination in access to land was one of the most politically potent symbols of the gross discrimination that marked South African society, disparities in access to water were, if anything, more pronounced. This continues to be felt, particularly in rural areas of South Africa, where Cullis and van Koppen (2007) have estimated Gini coefficients that suggest the considerable level of income inequality (Gini 0.64) is dwarfed by the disparity in direct water use (Gini 0.95). As in the case of land, this reflects historical exclusion of the black majority population from property rights in water under the apartheid regime (Woodhouse, 1995).

However, post-apartheid prospects of redistribution of land and water from existing 'haves' to 'have nots' raised considerably the political risks attached to the implementation of reform. Indeed, contemplating reform at the close of the apartheid era, a World Bank-funded centre for policy analysis in Johannesburg observed: 'the political will [needed] to amend the [water] law is probably greater than that required for land distribution' (LAPC, 1994, quoted in Woodhouse, 1995: 543). This observation arose from recognition that irrigated agriculture is the largest user of water in South Africa, and that access to irrigation is necessary for the financial viability of much of South Africa's commercial farming sector and a key element of private property in natural resource use under the apartheid regime. In this paper I argue that the nationalization of de jure private property in water under the National Water Act (1998) has yet to be felt in any diminution of de facto control of water resources by commercial agricultural entities inherited from the apartheid era.

In part, this is because agricultural water use represents something of a blind spot for popular political debate on water, which focuses on drinking water, identified as a distinct 'water sector'. This separation is reinforced by the fact that drinking water ('water services') is governed by a separate reform process under the Water Services Act (1997). The pre-eminence in public understanding of a 'water sector' delivering treated water for household consumption is understandable from the point of view of an urban majority population in South Africa. However this locates analysis of commodification of water in a perspective on (mostly urban) water services, and 
ignores the quite different dynamics that apply to (rural) agricultural water use. Specifically, the analysis of the commodification of water identifies water as a resource whose provision has hitherto been via a heavily subsidised public service, subject currently to processes of reduction of the role of the state (deregulation) and reregulation to promote marketization of water services. Case studies, such as those assembled by McDonald and Ruiters (2005), document struggles over this process, in which resistance is marshalled under the banner of water as a human right which cannot be negotiated according to market principles alone.

It is not to deny the importance of such arguments to observe that they apply to only 20 per cent of total water use. They ignore, therefore, the almost 60 per cent of water which is used by agriculture and which was largely controlled by commercial interests by the mid-twentieth century. If this agricultural water has been overlooked by the critical literature on water services commodification, it has also been neglected by the political narrative of land reform. Despite the necessarily intimate relationship between the outcomes of land reform and water reform, these have largely followed parallel paths governed by separate state agencies. In both cases, however, the pace of actual redistribution of resources to historically disadvantaged people has been slow. The consequences of the separation of land and water reform processes are now more frequently recognized. Greenberg (2010: 11) notes that 'many land reform farms have failed precisely because water has not been available for production', and he cites the National Planning Commission's recent emphasis on 'the alignment of water resource allocation with land reform' (Greenberg, 2010:10).

This article draws on a study spanning fifteen years that explored processes of reform of water management institutions in the north-east province of Mpumalanga, an area of intensive water use by commercial agriculture, and also the site of some of the largest land transfers under South Africa's land reform. The article identifies how water reform has interacted with processes of land reform in this area. It argues that a largely ineffective process of legislative reform of water governance has gained impetus from transfers of irrigated farms under land restitution claims. Despite this impact of land reform's 'facts on the ground', however, the outcomes of redistributive reform are far from clear. On the one hand, re-allocation of water to other, particularly small-scale, potential agricultural water users remains disabled by 
unresolved tensions within the processes of policy reform. On the other hand, the 'locking in' of land and water into existing patterns of commercial agriculture poses questions about the nature and trajectory of new forms of 'community' property being created by land reform. The paper begins with a brief review of the national progress of land and water reform in South Africa. It then provides an empirical account of the implementation of reform of water governance in the Inkomati river basin and identifies how the dynamics of water reform and land reform have interacted. The paper concludes with a discussion of the implications for wider debates on agricultural development and property rights in land and water.

\section{South Africa's Land reform}

The overall goal defined for South Africa's land reform was to transfer 30 per cent of white-owned agricultural land (24.9 million ha) to black farmers (Lahiff, 2008). This remained a distant prospect when land reform had only achieved the transfer of 4.3 per cent (of which a considerable element of state-owned land) in the first decade (1994-2004) of majority rule (Bernstein et al., 2005). However, continuing high levels of inequality, unemployment and poverty in South Africa have maintained political pressure to quicken the pace of land reform. A Land Summit in 2005 committed the government to renew its efforts to assist black farmers to purchase land through grants and loans, in order to achieve its redistribution goal of 30 per cent of commercial farmland by 2014. Despite a number of new initiatives this deadline has subsequently been postponed to 2025 (Greenberg, 2010).

South Africa's land reform embraces three distinct processes: restitution, redistribution and tenure reform. Restitution involved restoring to specific individuals or groups land from which they claimed they had been evicted as a result of racially discriminatory laws since 1913. Redistribution involved government-assisted purchase of white-owned farmland by black farmers on a 'willing buyer, willing seller' basis. Tenure reform aimed to improve security of tenure of people occupying land in areas reserved for black people ('Bantustans', later 'homelands', under apartheid), governed under customary or 'tribal' authority. In addition, legal measures were introduced, in the form of the Land Reform (Labour Tenants) Act (LTA) in 
1996 and the Extension of Security of Tenure Act (ESTA) of 1997 to protect farm workers from eviction from houses and land they occupied on the commercial farms where they worked.

Land restitution was originally due to be completed by the end of 2007 . About 70 per cent of claims had been settled by late 2005 (Bernstein et al., 2005), and the great majority of claims to land that now lies within urban areas had been resolved (usually by payment of cash compensation) by 2008 (Lahiff, 2008: 16). In rural areas, land claims more often involved transfer of ownership of land, existing (white) landowners being compensated by government at an agreed valuation of the land. The most delayed of restitution cases involved large areas of highly productive commercial farmland, among which land claims in Mpumalanga Province featured prominently. Nationally, it has been estimated that, by 2009 , the settlement of 75,787 restitution claims had resulted in the transfer of 2.62 million ha of land to black owners (Greenberg, 2010). Set against a total of 79,696 claims registered (Lahiff, 2008: 14), this suggests under 5 per cent (3909) of restitution claims remained unresolved by 2009. However, about a third of remaining unresolved claims are 'complex' — often subject to contestation by the existing owners, or by competing restitution claims to the same land, boundary disputes between customary authorities, or insufficient evidence of eviction - and result in lengthy hearings in the Land Claims Court (Lahiff, 2008: 17). Progress is consequently slow, but also costly. In 2011, the Department of Rural Development and Land Reform was spending R2.5bn on restitution claims, but with a target to resolve only 60 claims in a year. ${ }^{2}$

Land redistribution is expected to supply the greater part of the government's 30 per cent land transfer target. However, by 2009, this had transferred 3.04 million ha to black owners, equivalent to about 12 per cent of the target area. The redistribution programme has been the subject of criticism since its inception, both for its slow pace and also for its lack of impact, attributed to failure of government to provide financial and technical support to the black owners of transferred land. More fundamentally, opinion remains divided over the goals of land redistribution. Policy has been heavily influenced by those, including the government's Department of Land Affairs — now

\footnotetext{
${ }^{2}$ Star Business Report 26 October 2011.
} 
the Department of Rural Development and Land Reform (DRDLR) — who see the goal of land reform as transferring existing forms of commercial farming into black ownership. Others have argued for greater state intervention to create a market environment compatible with small-scale commercial agriculture on redistributed land (Cousins, 2011; Hall, 2009; Lahiff and Cousins, 2005). A further view sees land redistribution as providing security for rural communities in which '(M)ost households survive on welfare grants supplemented with subsistence agriculture and natural resources harvested from the commons' (Cousins and Hornby, 2007).

In practice, a succession of government schemes providing grants and loans for the purchase of farmland by black farmers has seen increasing emphasis on support for a class of entrepreneurial black commercial farmers. Thus, the Settlement and Land Acquisition Grant (SLAG), initiated in the 1990s, explicitly targeted poorer people who generally had to pool their grants in order to purchase a (large-scale) commercial farm, which they subsequently subdivided or attempted to run collectively. In 2001 the SLAG was replaced by the Land Reform for Agricultural Development (LRAD) scheme which provided larger grants and hence enabled existing commercial farms to be acquired by individuals. Following the Land Summit in 2005, the Proactive Land Acquisition Strategy (PLAS) allowed government to purchase land as it came up for sale, for later redistribution to black farmers. While this was intended to increase the pace of land transfers, according to Lahiff (2008) it effectively directed existing land purchase budgets to a smaller area of more productive land, to be redistributed in larger units to an elite of agricultural entrepreneurs.

Despite (or because of) this growing emphasis on the 'commercial viability' of redistributed farmland, there is growing concern at the perceived failure of the beneficiaries of land reform to gain adequate access to markets (for inputs and produce) and financial and technical services (Greenberg, 2010). This has prompted scrutiny of the capacity of government departments to deliver such services, and the DLA and its successor DRDLR are widely seen as lacking the human resources to plan and implement commercially 'viable' agricultural projects on redistributed land. Others have argued that notions of farm 'viability' are themselves open to competing interpretations and require more rigorous scrutiny within policy processes (Cousins and Scoones, 2010; Hall, 2009). 
The third element of land reform was intended to provide improved security of land tenure to the 17 million people living within the areas designated as 'homelands' under apartheid, where access to land was governed by customary, or 'tribal' authority. In practice, widespread public discontent with tribal authorities (Levin and Weiner, 1997; Ntsebeza, 1999) built pressure for reform, culminating in the 1999 Land Rights Bill. Controversially abandoned when a new Minister of Agriculture and Land Affairs was appointed, the Land Rights Bill was substituted by the Communal Land Rights Bill, passed into law in 2004 (Claassens and Cousins, 2008). While the 1999 Land Rights Bill specified rights to occupy and use land vested in individual members of self-defined groups, thus leaving scope for boundary definition, the Communal Land Rights Bill (CLRB) sought to transfer land titles to historically or administratively-defined (ethnic) 'communities', and land administration to a Land Administration Committee. A separate piece of legislation, the Traditional Leadership and Governance Framework Act (TLGFA) of 2003 provided for existing tribal authorities (constituted during the apartheid era) to become recognized as traditional councils provided that they met certain composition requirements (40 per cent of the membership to be elected and 30 per cent [subsequently lowered] to be women). Under the terms of the separate CLRA: 'If a community has a recognised traditional council, the powers and duties of the land administration committee of such community may be exercised and performed by such council'. Although the administration of land by tribal authorities had not been explicitly legislated in either bill, the combined effect of both was to produce that result (Smith, 2008: 61).

Implementation of the CLRA never took place, however, as a consequence of a constitutional challenge mounted by civil society and community organizations, and was eventually ruled unconstitutional by South Africa's Constitutional Court on 11 May 2010, the DRDLR having earlier indicated that it would not oppose the Court's ruling and would repeal and replace the Act (LRG, 2010). The question of land rights in former Bantustan areas remains unresolved, therefore, and this continues to have repercussions not only for the development of water resources for black farmers in such areas, but also for the content of new forms of community property created by land reform, as will be discussed in more detail later in this paper. 


\section{South Africa's Water Reform}

South Africa's National Water Act of 1998 (Act No 36 of 1998) is widely regarded as a pioneer of an international wave of reform in the water sector, including the EU Water Framework Directive (EU, 2000) and Mexico's National Water Plan (20012006), which embodied a set of guiding principles agreed at the 1992 International Conference on Water and the Environment (ICWE) in Dublin (Calder, 1999; Heathcote, 1998; World Bank, 1993, 2004). The key ICWE principles are:

1. The River Basin is a natural unit of analysis and management. A holistic approach to water management is advocated, i.e. Integrated Catchment Management.

2. Action should be taken at the lowest appropriate level (subsidiarity). This will necessitate the devolution/decentralization_of management.

3. Water has an economic value. Economic instruments should be used to encourage the efficient use of the resource.

4. A Participatory approach is advocated - all stakeholders (with particular reference to women) should be involved in the planning and management of water resources.

South Africa's water reform differs from the international norm, however, in making an explicit goal of the legislation the redress of past inequality in water use. Thus the purpose of the National Water Act (NWA) is stated (section 2) as follows:

To ensure that the nation's water resources are protected, used, developed, conserved, managed, and controlled in ways that take into account...

- meeting basic human needs of present and future generations;

- promoting equitable access to water;

- redressing the results of past racial and gender discrimination;

- promoting the efficient, sustainable and beneficial use of water in the public interest

- facilitating economic and social development;

- $\quad$ providing for growing demand for water use; 
- protecting aquatic and associated ecosystems and their biodiversity;

- reducing and preventing pollution and degradation of water resources;

- meeting international obligations;

- promoting dam safety;

- managing floods and droughts.

And, for achieving this purpose, to establish suitable institutions and to ensure that they have appropriate community, racial and gender representation. (emphasis added)

The goal of redressing past inequality means that South Africa's water reform is expected to deliver not only changes in process (holistic, decentralized, participatory and economically costed), but also a change in social outcomes (redistribution of water allocation). In practice, although nineteen Water Management Areas (WMAs) were designated soon after the NWA passed into law in 1998, the decentralized organizations envisaged to manage water - a Catchment Management Agency (CMA) for each WMA and Water Users Associations (WUAs) at more local scales have proven hard to operationalize. The first CMA was approved in 2004 for the Inkomati WMA but by 2011 had been joined by only one more (the Breede-Overberg CMA in the Western Cape). In 2012 the number of CMAs plannedwas reduced to nine. Moreover, the whole principle of delegation of functions to CMAs by the Department of Water and Affairs (DWA, formerly the Department of Water Affairs and Forestry - DWAF) had been called into question in the South African parliament (PMG, 2011). The following section outlines the dynamics and trajectory of water reform in the Inkomati Water Management Area and their intersection with land reforms being pursued — often by separate agencies — in the same geographical area.

\section{The Inkomati Water Management Area}

The Inkomati WMA is located in Mpumalanga Province, north-eastern South Africa, bordering Mozambique to the East and Swaziland to the South-East. It is made up of 
three principle river catchments: the Sabie-Sand, the Crocodile and the Komati (top to bottom on Map 1). All drain in an easterly direction and eventually flow into Mozambique. The water in the catchment is mostly generated by rainfall (up to $1500 \mathrm{~mm}$ per year) in the summer months on the Highveld plateau in the west $(2,000 \mathrm{~m}$ above sea level), and on the Great Escarpment, which divides the Highveld from the Lowveld (140m above sea level) to the east where rainfall is lower (400 to 1,000 mm) and temperatures higher. Annual evaporation rates vary across the WMA, from less than $1,400 \mathrm{~mm}$ on the Highveld to more than $1,900 \mathrm{~mm}$ in the Lowveld, and as a result irrigation requirements vary (DWAF, 2004), with higher demand in the drier and hotter Lowveld.

During the apartheid government, the black population was evicted from the highveld and escarpment and much of the lowveld, and resettled in a series of ethnicallydesignated 'homeland' areas in the lowveld, governed from the 1970s by tribal 'national' administrations funded by the South African state. The two homeland areas known as KaNgwane had a population of about 1.5 million by the turn of the century. The areas from whence people had been evicted were used for white-owned business: commercial forest plantations on the Highveld and escarpment, and irrigated agriculture, principally sugar cane and tropical fruit (citrus, banana, avocado, mango and macadamia), on the Lowveld. A substantial part of the eastern Lowveld is occupied by the Kruger National Park. Much of the highly-productive irrigated land was subject to restitution claims under the terms of South Africa's land reform. These included a claim to some 32000 ha of 'highly commercial' farmland in the lowveld, settled in June 2007 at a cost of R601 million (US\$ 12 million) to the government land restitution budget (Lahiff, 2008: 15).

\section{MAP HERE}

Water resource infrastructure (dams and canals) was well developed in the majority of the Inkomati WMA reserved for the white population, but with the end of apartheid a 
further burst of dam construction was initiated, with major dams constructed in the 1990s at Driekoppies (237 $\mathrm{M} \mathrm{m}^{3}$ capacity) and Maguga (303 $\mathrm{M} \mathrm{m}^{3}$ capacity) to provide water for irrigated agriculture, and at Injaka (120 $\mathrm{M} \mathrm{m}^{3}$ capacity), on a tributary of the Sabie, to augment domestic water supplies for the densely populated townships of the former homelands. Despite these investments, irrigated agriculture remains vulnerable to drought, with severe droughts in 1992-2003 and in 2003-05, and flooding - most recently in 2000. Estimates of water use in the WMA are subject to dispute (see below), but official figures (DWAF, 2004) state that irrigated agriculture accounts for 57 per cent of all water use, forestry plantations 11 per cent, industrial use (including inter-catchment transfers) 10 per cent, international treaty obligations (cross-frontier flows to Mozambique) 11 per cent, urban water supply 6 per cent, and rural water supply 2 per cent. More recent estimates (Water for Africa, 2006) claim demand for water for irrigation to be as high as 83 per cent of all water demand in the WMA, and that total demand is approximately double the water available in the catchment. Despite large discrepancies in such estimates, there is consensus that the WMA is 'water-stressed', particularly in the Lowveld stretches of the Crocodile and Komati catchments.

\section{Implementing Water Reform}

Under the terms of the National Water Act, all water in South Africa is considered to be an 'indivisible national asset', for which the government's Department of Water Affairs and Forestry is the custodian in the public interest (DWAF, 1997). Integrated catchment management is to be achieved following the principle of devolution/decentralization of water management in each Water Management Area to a single Catchment Management Agency (CMA), representing the interests of different water users at the catchment level. According to section 80 of the National Water Act, the CMAs will have three initial functions:

- To investigate and advise on the protection, use, development, conservation, management and control of water resources in its WMA.

- To develop a catchment management strategy. 
- To coordinate the related activities of water management institutions within the WMA.

The NWA provides that central government (DWAF) may delegate far-reaching powers to the CMA, phased over time as and when the CMA is deemed a 'responsible authority'. A key function, not initially delegated, is the issue of licences to replace 'existing lawful use' of water authorized under previous (apartheid) legislation. This will require all water users to apply for a licence to continue using water. Under licencing arrangements water may be re-allocated from existing use so as to achieve a fairer allocation of water, to improve the efficiency of resource management or to protect water quality (section 43). In order to undertake such a function, the CMA would effectively take over many of the operational functions currently undertaken by the DWAF regional office in Nelspruit. The staffing and operation of the CMA is to be funded by a water management charge levied on all water users, in addition to volumetric tariffs already charged for water use.

Within the WMA, water management at a local level is to be undertaken by Water Users' Associations (WUAs), defined as 'co-operative associations of individual water users who wish to undertake water-related activities for their mutual benefit'. Each WUA is to be managed by a management committee, and may charge its members to fund its activities.

The implementation of the CMA in the Inkomati WMA has been characterized by a struggle between the main local water users, particularly white-owned commercial farming interests, and officials of the DWAF national headquarters in Pretoria. This process, set out in more detail elsewhere (Brown and Woodhouse, 2006; Woodhouse and Hassan, 1999) involved a local consultation culminating in a proposal for catchment management based on 'executive committees' at the level of three subcatchments (the Sabie-Sand, the Crocodile, and the Komati). This proposal, submitted to DWAF in 2000, was rejected as dominated by existing large water users - the Irrigation Boards that represent and coordinate water use by commercial farmers and insufficiently representative of historically disadvantaged groups. 
Thereafter, local impetus for institutional change stalled until the Inkomati CMA was launched in March 2004 by the Minister for Water Affairs and Forestry, who also established an advisory committee to identify and propose membership of a Governing Board for the CMA. In September 2005 a Governing Board of 14 representatives of different sectors was given Ministerial approval, and in May 2006 a chief executive officer was appointed. Transfer of technical (water resource management) staff from the DWAF regional office to the CMA was due to take place in April 2007. This was suspended in November 2007 when the entire CMA programme was halted while an 'institutional re-alignment' review was conducted within DWAF in Pretoria. Ministerial initiative to operationalize the Inkomati CMA was renewed late in 2009, with a directive that the CMA submit its Catchment Management Strategy (CMS) as a step towards delegation of functions, and concomitant transfer of resources from the regional DWAF (now DWEA) in Nelspruit. With the submission of the CMS in May 2010, the Inkomati CMA had effectively reached the same point at which it had stalled three years earlier.

In the intervening three years, institutional reform had stagnated. The CMA Governing Board, which had seen its membership reduced from fourteen to eight through mortality and other attrition, had served its term of office and a new Board needed to be appointed. The Chief Executive Officer of the CMA in 2007 had departed in 2009 and had yet to be replaced in June 2011 (PMG, 2011). A degree of technical capacity had been established through staff recruitment, mostly at the expense of the regional DWAF office, contributing to a situation where two local agencies have water resource management responsibilities, but neither has the technical personnel to fully undertake all of them. Continuing disagreement between DWAF and the irrigation boards (IBs) on the role and constitution of the new Water Users Associations (see below) meant that IBs have not paid the water management charge which was to have funded the CMA. Instead, a limited CMA budget, covering little more than staff costs, has been provided by 'seed funding' from the central government treasury via DWAF. Such progress as has been made on water management has been heavily dependent on outsourcing work to consultants, often using external short-term 'project' funding. Separate teams of consultants were contracted to undertake the preparation of the CMA business plan (2005-06), and elements of registration and verification of existing water use in the WMA (2004-07, 
see below), and a further team of consultants was hired to undertake the drafting of the CMA's catchment management strategy (CMS) in 2007. This last failed to deliver, and the CMS was eventually completed by the CMA's own (ex-DWAF) staff in 2010 .

\section{Emerging Dynamics of Change}

Within the overall context of organizational reform outlined above, it is possible to identify four areas of contested change which have significantly influenced the outcomes of the water and land reforms in the Inkomati water management area. These are: firstly, the legacy of information asymmetry on water use in irrigation; second, the persistence of an institutional dualism separating water rights in commercial farming from that in former Bantustan areas; third, the impacts of land restitution claims on racial distribution of land and water use; and finally the reform of commercial farmers' irrigation boards to become more inclusive water users' associations.

\section{Information Asymmetries and Water Allocation Reform}

The process of water allocation reform in the NWA is premised on prior verification of 'existing lawful use' to establish a baseline upon which to base re-allocation (and licensing) decisions. To the extent that existing lawful use cannot be verified, therefore, water re-allocation is effectively stalled. This has emerged as a central issue confronting the redistribution of water from white to black water users in the Inkomati WMA. Little precise information exists in the public domain as to the actual amount of water used by the main existing water user: commercial agriculture. Irrigation boards (IBs) pay water charges according to official allocations made in the past by DWAF. However, there is dispute about how much water is actually used, and whether this exceeds the official allocations. Information on individual farmers' water use is held only by the IBs and by the farm operators themselves. This asymmetry has been inherited from the pre-reform period (Woodhouse and Hassan, 1999), but remains largely unchanged despite the increasing use of equipment for digital 
recording of irrigation pump operation. For example, some 190 devices transmitting data on pump operation (and permitting remote shut-down of pumping) were installed by ESKOM (the electricity utility) in 2008 on pumps in the lower Crocodile/Lower Lomati area to ensure irrigation pumping took place only at non-peak periods of electricity demand (in a context of acute electricity shortage in South Africa at the time). The digital records of pump operation thus generated provide accurate information on water use, but this is currently available only to the IBs and their members. The IBs provide the CMA and DWAF with only a monthly summary for $10 \mathrm{~km}$ stretches of river, thus keeping records of water use by individual farms out of the public domain. This maintains a significant asymmetry of information, favouring existing water users over 'emerging' or 'potential' water users, such as residents in ex-homeland areas seeking access to water for domestic and agricultural use. A limited programme (totalling 7094 ha) of irrigation of small-scale (7ha plots) sugar cane holdings was begun in the 1990s in the former KaNgwane area of Nkomazi, following the construction of the Driekoppies Dam. However, despite requests from black farmers' organizations for further irrigation, totalling about 19000 ha, no further allocations of water have been made for at least seven years, as local offices of the DWAF and the Department of Agriculture engage in arguments about whether sufficient 'unallocated' water is available to supply new agricultural projects.

In an effort to break through the paralyzing effects of lack of information on water use, the DWAF head office in Pretoria invoked the provisions of the NWA to undertake compulsory licensing of all water use in the Inkomati WMA. This required all existing water users to register the quantity and source of their water use during a specified 'qualifying period' (1996-98), and to register a formal application for future water use. Registered water use was then verified by means of satellite images for both the qualifying period and the current, or verification, period (2004). Following verification, DWAF was to formulate a proposal of overall water use for specific subcatchments, taking account of priorities to provide water for basic human needs and for ecosystem maintenance (together referred to as 'the reserve') and any international obligations. This proposal was then to be translated into allocations for individual farms, published as a 'preliminary allocation schedule', and subsequently finalized (subject to appeals heard by a water tribunal) in the form of licences issued to water users. 
It is important to observe that the verification process does not measure water use directly, but estimates it from the area irrigated within each farm boundary, as shown on the satellite images. In the Inkomati WMA, the initial verification stage indicated that in 2004 the total area of land being irrigated had increased by about 17000ha relative to that observed in 1996-98. Resolving whether this was due to more efficient irrigation, allowing more land to be irrigated with the same amount of water, or to an unlawful increase in the amount of water being used, requires officials to visit the farms concerned to investigate in more detail. In practice the procedure proved hugely time-consuming. The delays in establishing the CMA, the relatively sophisticated technical requirements of the exercise and the ever-present threat of litigation from influential local commercial farming interests, made it almost inevitable that water allocation reform would be implemented by DWAF acting as a central government agency - albeit using a team of specialists ('consultants') hired for the purpose. It was further undermined by the absence of any provision for it within the DWAF budget. Instead, recourse was made to 'donor' (UK government) project funding. Consequently, although the verification process remained incomplete when funding ran out at the end of the project cycle in 2007, the process was halted and only restarted when a new 'donor' (Belgian government) project (including a fresh cadastral survey of farms) was funded, in 2010. From the date of its inception, in 2004, until 2011 the water allocation reform process had yielded no redistribution of water from existing commercial agricultural use.

\section{A Continuing Dualism in Water Governance}

The stalled verification and licensing process continues to be seen as the basis of a reallocation through a reduction in the amount of water which commercial agricultural operators are licensed to use. However, its actual impact is likely to be heavily modified, if not completely overshadowed, by two other dynamics at work.

The first relates to the legacy of water governance in the KaNgwane 'homeland' under apartheid. Water rights in KaNgwane were held by the tribal administration, but, unlike land rights controlled directly by traditional authorities (chiefs), water 
notionally allocated by DWAF in the 1970s for KaNgwane development was administered by the Kangwane Department of Agriculture. When the homeland administration was dissolved after 1994, the Mpumalanga Provincial Department of Agriculture (DoA) inherited the water allocations and other responsibilities (and in some cases the staff) of the KaNgwane Department of Agriculture. Thus, it remains the case that for black farmers in the former homeland areas, there are no individual, or even group, water rights, but all water allocations for 'development projects' are aggregated and held by the DoA that is responsible for paying the respective water fees to DWA in Nelspruit.

In some respects this separate dispensation for residents in former homelands might be regarded as a rational way of administering water used by large numbers of smallscale users. There is no legal requirement for registration of 'schedule 1' use of untreated water resources (i.e. not provided via formal water service) for household use. Moreover a view expressed by DWA officials in Pretoria in 2010 is that individuals using water for household purposes, for watering livestock, and for smallscale irrigation in former homeland areas should be subject only to a 'general authorization' applicable to a defined area within which a water licence is not required. Such arguments are consistent with the use of the DoA as a collective proxy for water rights in former homeland areas.

However, two consequences are apparent in this continuing dualism of institutional access to water. Firstly, there is a risk that the DoA will act in lieu of a Water Users Association for black farmers in former Bantustan areas, undermining the wider participation and representation of this group of water users in the (eventually) reformed institutions of governance of water use. Secondly, and linked with this institutional separation, there is the historical legacy that the KaNgwane administration failed to develop infrastructure necessary to use the water notionally allocated to it - water that became 'allocated' by default to white commercial farmers. This suggests a risk that any present and future demands to increase investment in water infrastructure (e.g. canals or storage dams) in former homeland areas with implications for formal water allocation (licencing) for farmers in these areas will (re)produce the same response from water management institutions as they 
have since the apartheid era: that the Inkomati is a 'water-stressed' catchment and that all water has already been allocated.

\section{Land Restitution Impacts on Irrigated Agriculture}

A second dynamic, which some see as circumventing the paralysed water allocation reform process, is generated by large-scale transfer of commercial farmland to black communities as a result of land restitution claims: the restoration of ownership of land from which they were evicted under the apartheid regime. In the main sugar-cane growing areas of the lower Crocodile River, at least 40,000ha of commercial sugarcane and fruit orchards were subject to such claims. A number of existing white farmowners agreed to accept government compensation payments and in 2007 around 18,000 ha was transferred to the communities who had registered claims to them. Other landowners, organized as 'Onderberg pro-active' resisted restitution claims, and, aided by the failure of claimants to resolve competing claims to the same land by different communities, succeeded in having restitution claims withdrawn from about 23,000ha of commercial farmland (Land Claims Court, Randberg, 21/02/2011).

Leadership for claim settlements has come from the company that owns two sugar mills in the area, as well as 5000ha of the farmland subject to restitution claims. The company has been active in promoting the development of small-scale sugar production in the former homeland areas of Nkomazi and has set up a series of joint venture arrangements whereby commercial farms on restituted land have been maintained in large-scale commercial production. The joint venture typically involves a commercial agricultural company and the community who now own the land. In effect, the land is leased from the land-owning community by a production company jointly owned by a community trust and the commercial partner. The community (who typically number 2000-3000 people on a 2000-3000ha restitution claim) receive the lease income and also a share of the profits of the production company. This model, implemented with five community trusts in the Nkomazi area, offers the prospect of maintaining production on highly capitalized farms and (of particular importance for industrial sugar producers) maintenance of cane supply to the sugar 
mills. This type of model, now strongly advocated for both restitution claims and land redistribution projects in South Africa, is driven by two factors.

Firstly, land is generally not transferred in its 'natural' form, but as a commoditized asset of a highly capitalized business. However, the transfer of land does not bring with it the ownership of the moveable assets needed to farm it, such as irrigation equipment, farm machinery, or vehicles, necessitating further finance. This links to the second factor driving this particular form of land settlement: the relatively high failure rate of farms transferred from white to black ownership under the government's grant-assisted 'willing buyer, willing seller' (SLAG and LRAD) land redistribution schemes. Farm failures have been attributed to inadequate appraisal of farm potential (marginal farms have been offered for sale) and unrealistic business plans designed to maximize advisors' commissions paid by government (Joubert and Kruger, 2005). In contrast, sugar mill operators have a strong incentive to maintain land reform farms in production, not only to secure cane supply, but also because a significant transfer of its cane supply into black ownership contributes towards establishing itself as a site of 'black economic empowerment', rather than a refuge of white landed privilege. Further, it may be viewed as a means of safeguarding existing water allocations for sugar production. More than one official interviewed in the area commented that, with the transfer of land-ownership, perhaps there is now no need to pursue water reallocation from existing commercial farming use.

Experience elsewhere in South Africa (Davis and Lahiff, 2011; Derman et al., 2010; Tapela, 2005) suggests caution about the prospects of the joint venture business model improving the livelihoods of beneficiaries of land restitution. However, it is possible that incentive structures may vary. For example, failure of fruit farms transferred to black farmers might be regarded as reducing competition, thus diminishing incentives for the remaining commercial growers to provide support to the management of land reform farms. In contrast, sugar mills' need to operate at full capacity provides a clear incentive for the milling companies to make the joint venture model — and indeed other models such as the smallholder schemes commercially successful. 
However, the Inkomati WMA provides instances where the extent of declining productivity following land restitution has threatened the viability of commercial farmers' water access. In one irrigation board (IB) managing a shared canal for fruit producers in the Hazyview area, for example, about 40 per cent of the area irrigated was transferred to black communities as a result of restitution claims. Initial arrangements to operate the land as a joint venture using a farm management company foundered as a result of problems with loan agreements and, after two years, collapse of commercial revenue on the transferred land meant the IB was unable to retrieve water fees from the land-owning communities. This in turn meant the IB was unable to cover its payments to DWAF, which are invoiced according to water allocated, not water used. As a consequence, the remaining commercial producers within the IB were seeking to lease back about half the transferred land from its new owners in order to restore output to commercial levels and generate enough income to cover the IB's water allocation.

\section{Irrigation Boards and More Inclusive Local Water Governance}

The situation noted above exemplifies a new dynamic introduced by land reform into the protracted negotiation between existing IBs and the regional DWAF over the transformation of the IBs into water users associations (WUA). For almost six years, failure to agree on the role, membership and governance of WUA had resulted in little progress in reforming these local water management institutions. One consequence, noted above, was the refusal of IBs to collect water management charges, thus depriving the newly-formed CMA of its operating budget. By 2010, however, land restitution had started to undermine some IBs' ability to maintain business as usual, as illustrated above, and negotiations on a model constitution for WUAs was pursued with new urgency via an 'Irrigation Forum' for the Inkomati that brought together DWAF/DWA, CMA and IBs. Resolution of issues including operation of private infrastructure assets (dams, canals) by sub-groups of members within WUAs offered the prospect of the IBs joining with other water users (e.g. municipal administrations responsible for water and sanitation services) in forming more inclusive representative water management institutions at a local scale. Under the new arrangements the WUA would be formally contracted by the DWA to act as the Billing Agency, collecting all 
water charges from water users within its area. In return, the WUA could count on government support in payment enforcement (including legal action against payment defaulters).

\section{Separate Development in South Africa's Land and Water Reforms}

The roots of separation between land and water reform are not only to be found within South Africa. The perception of water primarily in terms of a 'service' (treated/potable water) delivered by a distinct 'sector', noted at the start of this paper, is also a feature of the United Nations' Millennium Development Goals (UN-MDG, 2009). Even when considered in broader, 'natural resource management' terms, international 'best practice' embodied in the ICWE principles emphasizes integrated management of water resources. Some have commented this may undermine integration with priorities beyond the water sector, translating development problems and goals as subordinate to the boundaries and hydrological dynamics of 'catchment management', rather than the other way round (Mollinga et al., 2007; Lenton and Muller, 2009: 208). It seems that the main vehicle for water reform, the CMA, may have fallen victim to this syndrome. The wide representation of water users' interests which the governing board was intended to provide has - in the Inkomati WMA at least - thus far proved an inadequate means of integrating specialist water management skills with local political and development agendas. As a consequence, the CMA has been increasingly questioned as a costly duplication of the functions of regional DWAF offices.

As noted earlier, the need to integrate land and water reform has been acknowledged at the highest policy levels, such as the National Planning Commission. In its 200914 Strategic Plan the Department of Water Affairs also identified alignment of land and water reform as an output under its strategic objective of improving water allocation (DWAF, 2008), though it is unclear whether this included water provision for land reform projects outside existing irrigation schemes. A review by van Koppen et al. (2009) indicates that initiatives on joint land and water development have focused on rehabilitation of existing small scale irrigation and have been short-lived. Similarly, despite increasing recognition of the importance of supplementing water 
supplies for small-scale agriculture, either for 'backyard irrigation' using piped water services (Main and Naidoo, 2008 cited in van Koppen et al., 2009: 23) or through rainwater harvesting and storage (Botha and de Lange, 2005), co-ordinated policy between DWAF and other government agencies appears ephemeral, at best.

The lack of integration between land and water reform is evinced in a fundamental difference in approach to commodification of resources. Land reform has been framed by the concept of land as private property, exchanged via payments at market rates, albeit payments funded by the state, and 'sales' compulsorily imposed by land claims courts in the case of restitution claims. In contrast, water reform has involved the abolition of many pre-existing forms (e.g. riparian rights) of private property in water. Under the NWA, licencing of private water use is subordinated to broader social (basic water needs), environmental, and international treaty priorities (collectively termed 'the reserve') as identified by the National Water Strategy. The 'reserve' is to be defined for all major catchments in South Africa. However, unlike the 30 per cent farmland reallocation target of land reform, there is no quantitative target for water resource re-allocation to historically disadvantaged individuals (HDIs), beyond the supply of piped drinking water.

In practice, the Inkomati case suggests that, in the absence of a 'headline' political target for re-allocation of water, DWAF's water reform has sought legitimacy in technocratic arguments based on sustainability and efficiency of water use. This has involved delays due to technical complexity, for example in calculating the size of 'the reserve'. The experience of verification of agricultural use in the Inkomati WMA also suggests that the approach has demanded more technical resources than the shrinking technical capacity of the DWAF can supply, and consequent paralysis of water allocation reform. In the event, such transfers of water as have occurred have been locked into commodified form as inputs to existing patterns of commercial farming.

It is important to note here Walker's (2005) argument that most black South Africans' primary concerns are over jobs, housing and the provision of basic services, and that it is only in the context of failure to satisfy these concerns for large numbers of black people that restoring access to land assumes political potency as a discourse of redress 
and restoration of dignity and citizenship. To the extent, therefore, that existing patterns of commercial agriculture conducted under joint venture arrangements with commercial 'strategic partners' can generate new sources of employment and investments in improved housing and services, they may indeed satisfy the land reform goals of many members of communities now owning restituted land in the Mpumalanga Lowveld.

It needs to be acknowledged, however, that this pattern of land and water reform has closed down alternatives. Beyond the particular relationships of capital, labour, land and water embodied in the commercial farms, the reforms point to a continuity in the 'collective property' imposed on African populations under apartheid. Thus, the persistence of a separate institutional process for water allocation to former homeland agriculture via the Provincial DoA means potential irrigators (as distinct from those farming on existing irrigated areas) in former homeland areas remain isolated from irrigation boards (future Water Users Association), and the statutory processes of registering and licencing water use. The question arises as to how such potential or aspiring agricultural water users are to achieve political pressure for change, or whether the current situation exemplifies the view that 'small-scale water uses are tolerated, as long as any new water uptake remains insignificant and....as long as the marginalised remain marginalised, there is no problem'(van Koppen et al., 2009: 28).

With respect to land, the new community trusts embody a collective form of property that is locked into the leasehold arrangements of joint venture farming. The trusts are necessarily linked to structures of traditional leadership and customary authority through which restitution claims were organized and legitimated. Assuming the joint venture enterprises are successful in commercial terms, and in the case of sugar farms in the Nkomazi area there appear to be strong corporate incentives to this end, they constitute new forms of community income to be managed, and raise questions how this will be articulated with structures of customary authority. The controversies over the Communal Land Rights Act illuminated contested interpretations over the nature of customary authority, and, in particular, arguments that models of downward accountability (from 'chiefs' to their communities) had been largely supplanted by the incorporation of customary leaders within authoritarian structures of 'tribal administration' under apartheid (Claassens and Hathorn, 2008). Questions therefore 
arise as to whether post-apartheid customary authority in South Africa is capable of relinquishing the autocratic mould in which it had been cast by the apartheid state. Tensions arising over such issues as chiefly control over land allocation have been evident in Nkomazi (King, 2005; Rangan and Glimartin, 2002) and this suggests potential contestation over the role of traditional authority in the administration of new resources from joint ventures, such as leasehold income and profit shares. The issue raised here is not simply one of individual versus collective property rights in the manner of de Soto (2000), but rather how notions of community property previously incorporated into state governance structures will be subject to new contestation and re-negotiation as a consequence of their insertion in corporate agriculture. A final observation is that, to the extent that it continues to see a future in South African agriculture framed by the politics of 'black economic empowerment', corporate capital will also need to find ways to engage with these processes of governance of community property. 


\section{REFERENCES}

Bernstein A., J. McCarthy and S. Dagut (2005) 'Land Reform in South Africa. A Twenty-First Century Perspective'. Policy in the Making Research Paper 14. Johannesburg: Centre for Development and Enterprise.

Botha M. and M. de Lange (2005) Revitalisation of Smallholder Rainfed and Irrigated Agriculture. Papers TT254/1,2,3/05. Water Research Commission, Pretoria.

Brown J. and P. Woodhouse (2006) 'Pioneering Redistributive Regulatory Reform: A Study of Implementation of a Catchment Management Agency for the Inkomati Water Management Area, South Africa', in M. Minogue and L. Cariño (eds) Regulatory Governance in Developing Countries, pp. 227-257. Cheltenham: Edward Elgar.

Claassens, A. and B. Cousins (2008) (eds) Land, Power and Custom. Controversies Generated by South Africa's Communal Land Rights Act. Cape Town: UCT Press.

Claassens, A. and M. Hathorn (2008) 'Stealing Restitution and Selling Land Allocations: Dixie, Mayaeyane and Makuleke', in A. Claassens and B. Cousins (eds) Land, Power and Custom. Controversies Generated by South Africa's Communal Land Rights Act, pp. 315-52. Cape Town: UCT Press.

Cousins, B. (2011) 'What is a Smallholder? Class-analytic Perspectives on Smallscale Farming and Agrarian Reform in South Africa', in P. Hebinck and C. Shackleton (eds) Reforming Land and resource Use in South Africa. Impact on Livelihoods, pp. 86-111. London: Routledge.

Cousins, B. and D. Hornby (2007) 'Land Rights: De Soto Solution not for SA', Business Day 13 January 2007.

Cousins, B. and I. Scoones (2010) 'Contested Paradigms of 'Viability' in Redistributive Land Reform: Perspectives from Southern Africa'. Journal of Peasant Studies 37(1): 31-66.

Calder I.R. (1999); The Blue Revolution. Land Use and Integrated Water Resources Management. London: Earthscan.

Cullis, J. and B. van Koppen (2007) 'Applying the Gini Coefficient to Measure Inequality of Water Use in the Olifants Water Management area, South 
Africa'. Research Report 113. Colombo: International Water Management Institute.

Davis, N. and Lahiff, E. (2011) 'Joint Ventures in South Africa's Land Reform Programme: Strategic Partnerships or Strategic Resource Grab?'. Paper presented at the International Conference on Global Land Grabbing Institute of Development Studies, University of Sussex (6-8 April).

Derman, B., E. Lahiff and E. Sjaastad (2010) Strategic Questions about Strategic Partners: Challenges and Pitfalls in South Africa's New Model of Land Restitution', in C. Walker, A. Bohlin, R. Hall and T. Kepe (eds) Land, Memory, Reconstruction and Justice. Perspectives on Land Claims in South Africa, pp. 306-324. Athens, OH: Ohio University Press.

DWAF (2004) 'Inkomati Water Management Area: Internal Strategic Perspective'. Pretoria: Department of Water Affairs and Forestry.

DWAF (1997) 'White Paper on a National Water Policy for South Africa'. Pretoria:

Department of Water Affairs and Forestry. http://www.dwaf.gov.za/Documents/Policies/nwpwp.pdf

EU (2000) 'Water Framework Directive'. http://ec.europa.eu/environment/water/water-framework/index_en.html Greenberg, S. (2010) 'Status Report on Land and Agricultural Policy in South Africa 2010'. Research Report 40. Institute for Poverty, Land and Agrarian Studies, University of the Western Cape.

Hall, R. (2009) (ed) 'Another Countryside? Policy Options for Land and Agrarian reform in South Africa'. Cape Town: Institute for Poverty, Land and Agrarian Studies.

Heathcote, I. (1998) Integrated Watershed Management - Principles and Practices. New York: John Wiley \& Sons.

Joubert, R. and G. Kruger (2005) 'Land Reform and Redistribution Implementation in the Mpumalanga Province Sugar Industry, South Africa: A Process Approach'. RICS Research Paper Series. London: Royal Institute of Chartered Surveyors.

King, B. (2005) 'Spaces of Change: Tribal Authorities in the Former KaNgwane Homeland, South Africa', Area 37(1): 64-72.

van Koppen, B., H. Sally, M. Aliber, B. Cousins and B. Tapela (2009) 'Water Resources Management, Rural Redress and Agrarian Reform'. Development 
Planning Division Working Paper Series No 7. Halfway House: Development Bank of Southern Africa.

Lahiff, E. (2008) 'Land Reform in South Africa: A Status Report 2008'. Research Report 38. Programme for Land and Agrarian Studies, University of the Western Cape.

Lahiff, E. and B. Cousins (2005) Smallholder Agriculture and Land Reform in South Africa. IDS Bulletin 36(2): 127-31.

Lenton, R. and M. Muller (2009) Integrated Water Resources Management in Practice. London: Earthscan.

Levin, R. and D. Weiner (1997) (eds) "No More Tears": Struggles for Land in Mpumalanga, South Africa. Trenton, NJ: Africa World Press.

LRG (2010) 'Press Statement on the Constitutional Court Judgement on the Communal Land Rights Act'. Law Race and Gender Unit, University of Cape Town. www.lrg.uct.ac.za (accessed 17 May 2010).

McDonald, D. and G. Ruiters (2005) (eds) The Age of Commodity. Water Privatization in South Africa. London: Earthscan.

Mollinga, P.P., R.S. Meinzen-Dick and D.J. Merrey (2007) 'Politics, Plurality and Problemsheds: A Strategic Approach for Reform of Agricultural Water Resources Management', Development Policy Review 25(6): 699-719.

Ntsebeza, L. (1999) Land Tenure Reform in South Africa: An Example from the Eastern Cape Province. Drylands Programme Issue paper No 82. London: International Institute for Environment and Development.

PMG (2011) 'Breede-Overberg and Inkomati Catchment Management Agencies: 2011/12 Strategic Plans, Budgets, Annual Financial Statements, Key Performance and Priority Areas'. Parliamentary Monitoring Group. http://www.pmg.org.za/print/27077

Rangan H. and M. Gilmartin (2002) Gender, Authority, and the Politics of Land Reform in South Africa. Development and Change 33(4): 633-58.

Smith, H. (2008) 'An Overview of the Communal Land rights Act11 of 2004', in A. Claassens and B. Cousins (eds) Land, Power and Custom. Controversies generated by South Africa's Communal Land Rights Act, pp. 35-71. Cape Town: UCT Press.

de Soto, H. (2000) The Mystery of Capital: Why Capitalism Triumphs in the West and Fails Everywhere Else. New York: Basic Books. 
Tapela, B. (2005) 'Joint Ventures and Livelihoods in Emerging Small-Scale Irrigation Schemes in Greater Sekhukhune District: Perspectives from Hereford'. Research report 21. Cape Town: Institute for Poverty, Land and Agrarian Studies.

UN-MDG (2009) United Nations Millenium Development Goals 2009 Report. http://www.un.org/millenniumgoals/pdf/MDG_Report_2009_ENG.pdf

WALKER, C. (2005). The Limits to Land Reform: Rethinking the Land Question. Journal of Southern African Studies. 31 (4): 806-824.

Water for Africa (2006) 'Inkomati WMA Catchment Assessment Report'. Pretoria: Department of Water Affairs and Forestry, and Department for International Development (UK).

Woodhouse, P. and R. Hassan (1999) 'Implementation of the National Water Act.

Catchment Management Agencies: Interests, Access and Efficiency. Inkomati Basin Pilot Study'. Prepared for DWAF, South Africa and DIFD-Southern Africa, UK.

http://www.sed.manchester.ac.uk/idpm/research/publications/wp/rr/documents /rr_wp12.pdf

Woodhouse, P. (1995) 'Water Rights and Restructuring in South Africa: a case study from Eastern Transvaal', Water Resources Development 11(4): 527-44.

World Bank (1993) 'Water Resources Management Policy Paper'. http://siteresources.worldbank.org/INTWRD/214573-

1111579063201/20424649/WRMExSumof1993WaterPolicy.pdf

World Bank (2004) 'Water Resources Sector Strategy: Strategic Directions for World Bank Engagement'. http://lnweb18.worldbank.org/ESSD/ardext.nsf/18ByDocName/TheWorldBan kWaterResourcesSectorStrategyentiredocument255MB/\$FILE/WaterStrategyFullDocument.pdf http://documents.worldbank.org/curated/en/2004/01/3886596/water-resourcessector-strategy-strategic-directions-world-bank-engagement 